\title{
THE LIFE-HISTORY TRAITS AND SEEDLING RECRUITMENT OF Dianthus superbus L. IN DIFFERENT STAGES OF MEADOW OVERGROWING
}

\author{
Kinga Kostrakiewicz-Gierałt
}

\author{
Institute of Botany Jagiellonian University, Lubicz 46, 31-512 Krakow, Poland \\ e-mail:kinga.kostrakiewicz@uj.edu.pl
}

Received: 04.12.2013

\section{Abstract}

A study of the life-history traits and seedling recruitment in small and isolated populations of a rare clonal species, Dianthus superbus L., was carried out in the years 2011-2012 in Kraków-Kostrze (Southern Poland). Observations were conducted in unmanaged Molinietum caeruleae meadows situated along the successional gradient. The patch representing the initial stage of succession (P1) was dominated by small species creating delicate erect or procumbent stems, the patch representing the temporary stage of succession (P2) was prevailed by large-tussock grasses and tall-growing macroforbs, while the patch representing the terminal stage of succession (P3) was partly overgrown by bushes and trees. The number of generative shoots, flowers, fruits and seeds of Dianthus superbus L. diminished gradually from P3 via P2 to P1. The increase in abundance of generative shoots and flower number in the vicinity of tall plants contributes to increased visibility of inflorescences and may enhance the chances for nocturnal pollinator visits. A significant production of fruits and seeds in competitive neighborhood may augment the chances for successful dispersal and colonization of new, perhaps more favorable habitats. The recruitment of seedlings occurred only in artificially created gaps in plant canopy and litter. The appearance of seedlings and their survivorship were better in P1 than in P2 and P3. Such a phenomenon might be due to the locally rising water level and the diminishing amount of light reaching to the soil area along the successional gradient.

Concluding, it should be asserted that a low production of generative shoots, flowers, fruits and seeds by the population of Dianthus superbus L. established in the patch dominated by small meadow species is compensated by the highest seedling recruitment and their survival. On the other hand, a substantial production of generative structures is not sufficient to ensure the persistence of populations in meadows in advanced stages of secondary succession.

Key words: Dianthus superbus, generative shoot; flowers; fruits; secondary succession; seeds; seedling recruitment; seedling survivorship

\section{INTRODUCTION}

During the $20^{\text {th }}$ century, traditional agricultural management in semi-natural communities was either heavily intensified or abandoned in Europe. Unmanaged lands were subjected to secondary succession and gradual encroachment of tall-growing macroforbs, shrubs and trees. Such phenomenon, directly leading to the deterioration and fragmentation of habitats, was repeatedly observed in calcareous grasslands [1], heathlands $[2,3]$ and meadows $[4,5,6]$. As a result of advanced fragmentation of habitats, many species currently occur as small and isolated populations, suffering from loss of genetic diversity and high risk of extinction. The management of rare plant populations is facilitated by knowledge of the variability of life-history traits shaping the reproductive success, i.e. number of generative shoots, flower and fruit production, seed set, as well as knowledge of recruitment and survival of seedlings. Hitherto, such investigations have been carried out in populations of several taxa, such as Carex davalliana L. [7], Dactylorhiza majalis (Rchb.) P.F. Hunt \& Summerh [8], Genista anglica L. [9], G. pilosa L. [9], Gentiana pneumonanthe L. [10, 11], Orchis mascula 1. [12], O. purpurea Huds. [13], Senecio coincyi Rouy [14], and Succisa pratensis Moench. [7]. Despite of the growing interest in the above-mentioned issue, the reproductive success of several species still remains poorly understood. Considering the insufficient state of knowledge, investigations were undertaken in small populations of Dianthus superbus L. located in Molinietum caeruleae meadows in different stages of overgrowing. The main goals were focused on the evaluation of the influence of site conditions on: (1) the variability of life-history traits such as production of generative shoots, flowers, fruits and seeds; (2) the number and survivorship of seedlings in continuous plant cover and in artificially made gaps. 


\section{MATERIALS AND METHODS}

\section{Study species}

Large pink Dianthus superbus L. is a loosely tufted perennial, clonal forb which consists of numerous vegetative and generative shoots. The generative shoots are topped with many flowers visited exclusively by migratory crepuscular and nocturnal hawkmoths [15]. The fruits, greenish four-valved capsules, contain self-sowing seeds. The large pink is listed as a species of the Euro-Siberian subelement, widely but patchily distributed in western, central and eastern Europe as well as in northern Asia [16]. In Poland the greatest number of localities occur in the Vistula valley, whereas the lowest density of stands is recorded in the Baltic coastal area and western Pomerania [17]. Dianthus superbus L. is a rare and strictly protected plant in Poland [18] and is included to The Red List of Vascular Plants [19].

\section{Study area}

The study was carried out in the Kostrze district located on the western edge of Krakow, south of the Vistula River (southern Poland) (Fig. 1). The patches of Molinietum caeruleae occurring in this locality are relicts of vast meadows, which previously existed along the Vistula River [20]. The abandonment of traditional land use for at least a dozen years promoted the development of Phragmites swamps and willow brushwoods leading to fragmentation of meadows [21, 22].

\section{Description of the study site}

The investigations were carried out simultaneously in three abandoned patches of Molinietum caeruleae representing the successional gradient of meadow overgrowing (Table 1). Patch P1 was established in a meadow being in the initial stage of succession. It was dominated by small-stature taxa intercepting a very low amount of irradiance, contributing to strong insolation and a fast decrease in groundwater level in early spring. Patch P2 was set in a meadow being in the temporary stage of succession. It was predominated by grasses forming large tussocks and tall-growing macroforbs. The closely packed shoots and leaves shaded the whole patch, while the hummocks-and-hollow micro-topography triggered the prolonged water. Patch P3 was established in a meadow being in the terminal stage of succession. It was overgrown by shrub willows and surrounded by groups of trees. The elevation of water level in the local depressions provided high soil water content till late spring or even early summer. Moreover, the compact canopy of willow leaves strongly decreased the amount of light reaching ground level.

\section{Vegetation study}

In all patches the evaluation of habitat factors such as light intensity at ground level, vegetation he- ight, vascular plant cover and moss cover, was performed from the $3^{\text {rd }}$ to $15^{\text {th }}$ of July 2011 . The mean light intensity at ground level was calculated on the basis of 10 measurements performed with a digital light meter Voltcraft MS-1300 (accuracy +/- 5\% + 10 digits; measuring range 0.01-50 $000 \mathrm{~lx}$ ). Five measurements were performed on sunny days and five on cloudy ones. The average vegetation height was evaluated on the basis of measurements of 50 randomly chosen shoots of different species. Each shoot was measured from the ground level to the tip using a folding tape measure. The cover of vascular plants and the cover of mosses were visually estimated within an aluminum frame $(30 \mathrm{~cm} \times 30 \mathrm{~cm})$ in 50 randomly chosen places.

\section{Study of Dianthus superbus L. traits}

The research was carried out in the period 20112012. In 2011 all aggregations of shoots of Dianthus superbus $\mathrm{L}$. that occurred in the studied patches were marked with small plastic pegs. Individuals consisted of one shoot only were not observed in the study area. Subsequently, the number of generative shoots per aggregation as well as the number of flowers and fruits per generative shoot were counted in the years 2011 and 2012 separately. Seed production was evaluated in 10 capsules randomly chosen in each patch in 2012. The permit for capsule collection was issued by the Regional Director for Environmental Protection in Kraków. After counting, all seeds were scattered near the shoot aggregations.

Moreover, 10 permanent experimental plots $(0.5 \times 0.8 \mathrm{~m})$ were randomly arranged in each patch in April 2011 to assess the spontaneous recruitment of seedlings. The experimental plots were established at least 3.0 metres from the patch border to avoid the edge effect. Each plot was divided into two square-shaped adjacent subplots measuring $900 \mathrm{~cm}^{2}$. In one subplot, the established vegetation and litter were left untouched, while in the second subplot moss, plant canopy and decayed organic matter were clipped and removed. Such treatment is considered to be optimal for seedling establishment on the basis of the results of observations carried out in wet meadows [23, 24]. The establishment of generative offsprings was monitored once a week in May, June, July and August, and twice a month in April, September and October. Each seedling was tagged and the survived individuals were counted in 2012.

The nonparametric Kruskal-Wallis test and post-hoc test were applied to check the significance of the differences between patches P1, P2 and P3 in the number of: generative shoots per shoot aggregation, flowers per generative shoot, fruits per generative shoot, and seeds per capsule. Also, the aforementioned tests were used to check the significance of the differences 
in the number of seedlings per gap as well as the number and percent of individuals that survived in openings till next year.
Post-hoc comparisons were made if the value of the test was significant. All statistical analyses were performed using STATISTICA 10 software.

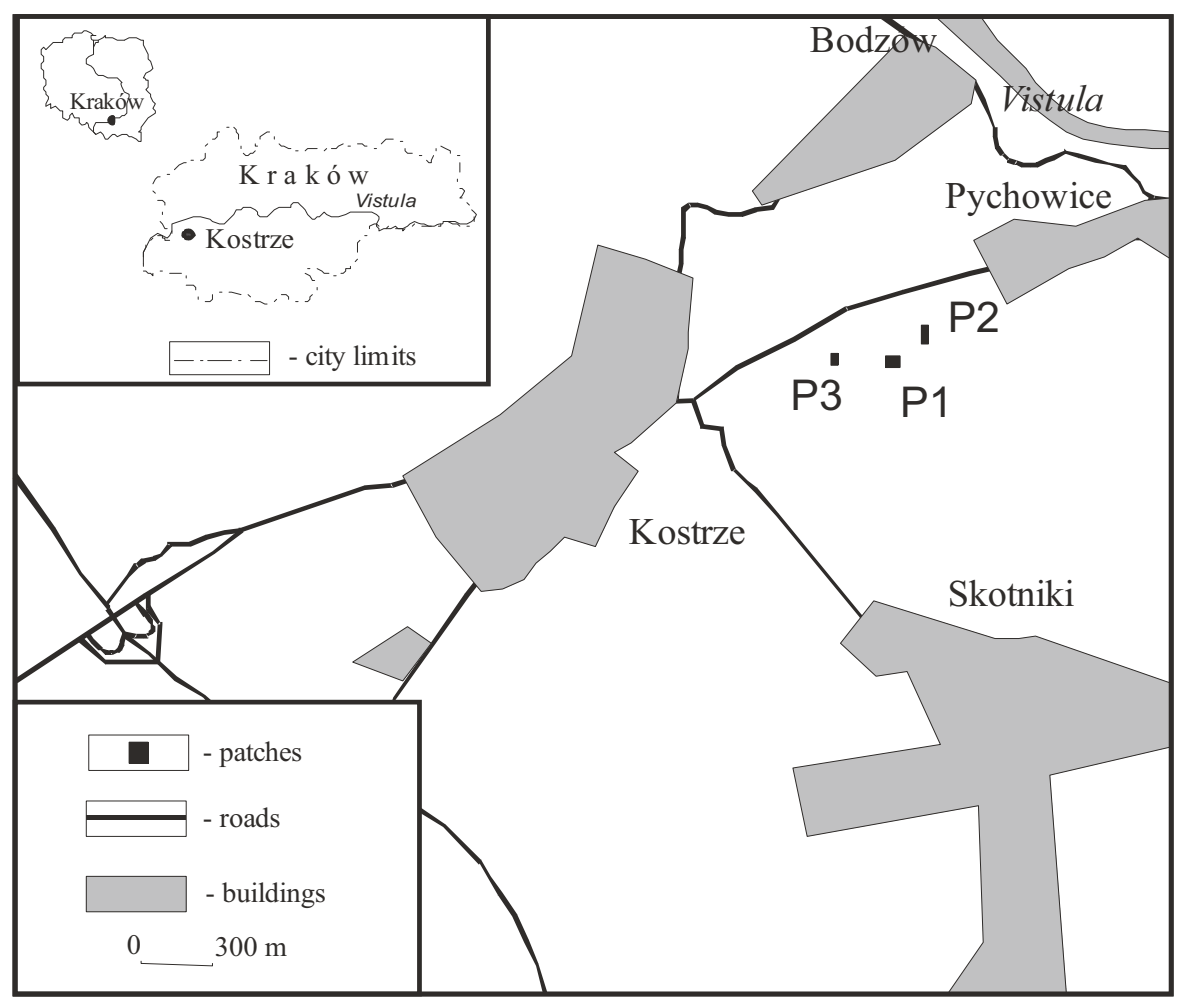

Fig. 1. The location of Dianthus superbus L. populations in the study patches representing the initial (P1), temporary (P2) and terminal (P3) stages of succession.

Table 1

Characteristics of the study patches

\begin{tabular}{|c|c|c|c|}
\hline Patch name & P1 & $\mathrm{P} 2$ & P3 \\
\hline Successional stage & initial & temporary & Terminal \\
\hline \multirow[t]{2}{*}{ Coordinates } & N 50 $01^{\prime} 50.4^{\prime}$ & N 50 $01^{\circ} 52.5^{\prime}$ & N 50 $01^{\circ} 50.9^{\prime}$ \\
\hline & E $19^{\circ} 52^{\prime} 03.2^{\prime}$, & E $19^{\circ} 52^{\prime} 03.0^{\prime}$, & E $19^{\circ} 52^{\prime} 02.9^{\prime}$, \\
\hline Patch area $\left(\mathrm{m}^{2}\right)$ & 1400 & 1300 & 1450 \\
\hline Mean light intensity at ground level (lx) & 43000 & 32000 & 20000 \\
\hline Mean vegetation height $(\mathrm{cm})$ & 64 & 78 & 136 \\
\hline Mean cover of herb layer $(\%)$ & 97 & 98 & 99 \\
\hline Mean moss cover $(\%)$ & 2 & 2 & 1 \\
\hline Species number & 76 & 61 & 48 \\
\hline Dominants & Lathyrus pratensis L. & Molinia caerulea (L.) Moench & Salix repens \\
\hline \multirow[t]{3}{*}{ (species with cover exceeding $20 \%$ ) } & Lotus corniculatus L. & $\begin{array}{c}\text { Deschampsia cespitosa }(\mathrm{L} .) \\
\text { P.Beauv }\end{array}$ & ssp. rosmarinifolia (L.) Hartm. \\
\hline & Lychnis flos-cucculi $\mathrm{L}$. & & S. cinerea $\mathrm{L}$. \\
\hline & Gladiolus imbricatus L. & & S. aurita L. \\
\hline Subdominants & Briza media L. & Filipendula ulmaria (L.) Maxim. & Populus tremula $\mathrm{L}$. \\
\hline \multirow[t]{2}{*}{ (species with cover of 5-20\%) } & Stelaria graminea L. & Serratula tinctoria L. & Betula pendula Roth \\
\hline & & $\begin{array}{c}\text { Phragmites australis (Cav.) Trin. } \\
\text { ex Steud. }\end{array}$ & \\
\hline
\end{tabular}


Table 2

Mean values characterizing the life-history traits of Dianthus superbus in the study patches representing the initial (P1), temporary (P2) and terminal (P3) stages of succession. Different letters indicate statistically significant differences obtained in post-hoc comparison (Kruskal-Wallis test).

\begin{tabular}{|c|c|c|c|c|c|}
\hline Life-history trait & Year & $\mathrm{P} 1$ & $\mathrm{P} 2$ & $\mathrm{P} 3$ & Test value, $P$ \\
\hline \multirow{2}{*}{ Generative shoots per shoot aggregation } & 2011 & $\begin{array}{c}1.80^{\mathrm{ab}} \\
\mathrm{N}=13\end{array}$ & $\begin{array}{c}3.13^{\mathrm{a}} \\
\mathrm{N}=15\end{array}$ & $\begin{array}{c}5.30^{\mathrm{b}} \\
\mathrm{N}=10\end{array}$ & $7.74, P \leq 0.05$ \\
\hline & 2012 & $\begin{array}{c}2.00^{\mathrm{ab}} \\
\mathrm{N}=13\end{array}$ & $\begin{array}{c}3.53^{\mathrm{a}} \\
\mathrm{N}=15\end{array}$ & $\begin{array}{c}6.70^{\mathrm{b}} \\
\mathrm{N}=10\end{array}$ & $9.13, P \leq 0.05$ \\
\hline \multirow{2}{*}{ Flowers per generative shoot } & 2011 & $\begin{array}{c}7.95^{\mathrm{a}} \\
\mathrm{N}=22\end{array}$ & $\begin{array}{l}11.25^{\mathrm{a}} \\
\mathrm{N}=47\end{array}$ & $\begin{array}{l}16.33^{b} \\
\mathrm{~N}=53\end{array}$ & $26.52, P<0.001$ \\
\hline & 2012 & $\begin{array}{c}6.33^{\mathrm{a}} \\
\mathrm{N}=21\end{array}$ & $\begin{array}{l}11.73^{b} \\
\mathrm{~N}=53\end{array}$ & $\begin{array}{l}15.16^{\mathrm{c}} \\
\mathrm{N}=67\end{array}$ & $35.52, P<0.001$ \\
\hline \multirow{2}{*}{ Fruits per generative shoot } & 2011 & $\begin{array}{c}5.54^{\mathrm{a}} \\
\mathrm{N}=22\end{array}$ & $\begin{array}{c}9.12^{\mathrm{b}} \\
\mathrm{N}=47\end{array}$ & $\begin{array}{l}11.75^{b} \\
\mathrm{~N}=53\end{array}$ & $21.48, P<0.001$ \\
\hline & 2012 & $\begin{array}{c}4.76^{\mathrm{a}} \\
\mathrm{N}=21\end{array}$ & $\begin{array}{c}8.67^{\mathrm{b}} \\
\mathrm{N}=53\end{array}$ & $\begin{array}{l}10.47^{b} \\
\mathrm{~N}=67\end{array}$ & $27.61, P<0.001$ \\
\hline Seeds per capsule & 2012 & $\begin{array}{l}40.83^{\mathrm{a}} \\
\mathrm{N}=30\end{array}$ & $\begin{array}{c}52.33^{\mathrm{ab}} \\
\mathrm{N}=30\end{array}$ & $\begin{array}{l}61.66^{b} \\
N=30\end{array}$ & $13.22, P<0.01$ \\
\hline
\end{tabular}

Table 3

Recruitment and survivorship of Dianthus superbus seedlings in 10 artificially made openings in the study patches representing the initial (P1), temporary (P2) and terminal (P3) stages of succession.

Different letters indicate statistically significant differences obtained in post-hoc comparison (Kruskal-Wallis test).

\begin{tabular}{lccccc}
\hline & Year & P1 & P2 & P3 & Test value, $P$ \\
\hline Seedling number & 2011 & $14.50^{\mathrm{ab}}$ & $9.60^{\mathrm{a}}$ & $6.70^{\mathrm{b}}$ & $15.57, P<0.01$ \\
Number of individuals that survived till next year & 2012 & $8.60^{\mathrm{a}}$ & $3.30^{\mathrm{a}}$ & $2.80^{\mathrm{b}}$ & $16.74, P<0.01$ \\
Percent of individuals that survived till next year & 2012 & $58.80^{\mathrm{a}}$ & $65.95^{\mathrm{a}}$ & $41.10^{\mathrm{b}}$ & $11.73, P<0.01$ \\
\hline
\end{tabular}

\section{RESULTS}

In the surveyed patches, the number of shoot aggregations of Dianthus superbus L. was rather low and reached 13 in P1, 15 in P2, and 10 in P3. The greatest number of generative shoots per aggregation was found in P3 where it amounted from 5.30 to 6.70 on average, a much lower number was recorded in patch $\mathrm{P} 2$, from 3.13 to 3.53, and in P1, from 1.80 to 2.00 (Table 2). The greatest number of flowers per generative shoot was observed again in patch P3, where it was from 15.16 to 16.33 . A lower production of flowers was found in patches P2 and P1 where it reached from 11.25 to 11.73 and from 6.33 to 7.95 , respectively. Also the number of fruits per generative shoot increased with the augmentation of shading level. It ranged from 4.76 to 5.54 in $\mathrm{P} 1$, from 8.67 to 9.12 in $\mathrm{P} 2$, and from 10.47 to 11.75 in P3. Similarly, the production of seeds substantially increased along the successional gradient.

In all populations, seedlings were recorded only in gaps artificially made in plant canopy and litter. The greatest emergence of generative offsprings was obse- rved in P1, whereas much lower recruitment rates were noted in patches P2 and P3. Similarly, the survivorship of generative offsprings was significantly higher in P1 than in P2 and P3 (Table 3).

\section{DISCUSSION}

The increased abundance of generative shoots and flower number in Dianthus superbus L. populations occurring in the vicinity of tall plants contributes to increased visibility of inflorescences and may enhance the chances for nocturnal pollinator visits. A positive correlation between flower display and activity of crepuscular pollinators, ensuring pollen receipt and donation, was observed by $\mathrm{S}$ o $\mathrm{m}$ a n a th a $\mathrm{m}$ and B org e s [25]. The increase in capsule and seed production in the populations of Dianthus superbus L. along the successional gradient is in accordance with the observations carried out in the populations of other species inhabiting abandoned Molinietum caeruleae. An increase in fruit number with the rising height of standing vegetation was found in the populations of Trollius europaeus L. [26] and Gentiana pneumonanthe L. [27], 
whereas an increase in seed output was recorded in the populations of Iris sibirica L. [28]. According to the models developed by Loechle [29] as well as by $\mathrm{G}$ ard ne r and M a n ge 1 [30], a significant production of fruits and seeds in competitive neighborhood may augment the chances for successful dispersal and colonization of new, perhaps more favorable habitats.

The results obtained during the present study, showing that recruitment of seedlings may occur only in gaps in plant cover and litter, support observations carried out in populations of other taxa, such as Dactylorhiza incarnata (L.) Soó [31], Gentiana pneumonanthe L. [32], Gladiolus imbricatus L. [33], Iris sibirica L. [28], Succisa pratensis Moench. [34], and Viola palustris L. [35]. The gradual decline in emergence of Dianthus superbus L. offsprings along the successional gradient is in agreement with observations of gap colonization by individuals of Trollius europaeus L. and Iris sibirica L. in unmanaged wet meadows [36]. The decrease in the number of seedlings and juveniles might be due to unfavorable habitat conditions. The rising water level in hollows between grass tussocks or in local depressions appearing between creeping shoots of willows may inhibit seed germination. According to B l a n e y and K o t a n e n [37] as well as Schafer and Kotanen [38], an increase in soil moisture in wet habitats accelerates the development of pathogenic fungi which damage the diaspores of many species. At the same time, it should be added that seeds of Dianthus superbus L. are very susceptible to pathogen attack [39] and loss of germination ability [40]. The decreasing light availability at ground level seems to be another factor strongly limiting the establishment and survivability of seedlings of Dianthus superbus L. in successive patches. According to Is selstein et al. [41], Kotowski et al. [42] as well as Kotowski and van Diggelen [43], the diminishing amount of light reaching the soil area in fen meadows may suppress the growth of plantlets or even trigger their mortality.

In conclusion, it should be stated that a low production of generative shoots, flowers, fruits and seeds by the population of Dianthus superbus L. established in the patch dominated by small meadow species is compensated by the highest recruitment of seedlings and their survival. On the other hand, a substantial production of generative structures is not sufficient to ensure the persistence of populations in meadows in advanced stages of secondary succession.

\section{Acknowledgements}

I would like to express my gratitude to anonymous reviewers for valuable remarks enabling considerable improvement of earlier version of manuscript.

\section{REFERENCES}

1. Poschlod P, Wallis DeVries MF. The historical and socioeconomic perspective of calcareous grasslands - lessons from the distant and recent past. Biol. Conserv. 2002; 104: 361-376. http://dx.doi.org/10.1016/S0006-3207 (01)00201-4

2. Mitchell RJ, Marrs RH, Le Duc MG, Auld MHD. A study of succession on lowland heaths in Dorset, southern England: Changes in vegetation and soil chemical properties. J. Appl. Ecol. 1997;34(6): 1426-1444. http://dx.doi.org/ $10.2307 / 2405259$

3. Fagúndez J. Heathlands confronting global change: drivers of biodiversity loss from past to future scenarios. Ann Bot. 2011; 111 (2): 151-172. http://dx.doi.org/10.1093/ aob/mes 257

4. Truus L, Puusild E. Species richness, biomass production and recent vegetation changes of Estonian floodplain grasslands. Pol. J. Ecol. 2009; 57(1): 33-45.

5. Rosenthal G. Secondary succession in a fallow central European wet grassland. Flora. 2010; 205(3): 153-160. http://dx.doi.org/10.1016/j.flora.2009.02.003

6. Opdekamp W, Beauchard O, Backx H, Franken F, Cox, TJS, van Diggelen R. et al. Effects of mowing cessation and hydrology on plant trait distribution in natural fen meadows. Acta Oecologica. 2012; 39: 117-127. http://dx.doi.org/10.1016/j.actao.2012.01.011

7. Hooftman DAP, van Kleunen M, Diemer M. Effects of habitat fragmentation on the fitness of two common wetland species, Carex davalliana and Succisa pratensis. Oecologia. 2003; 134(3): 350-359 http://dx.doi.org/ 10.1007/s00442-002-1096-0

8. Mróz L, Kosiba P. Variation in size-dependent fitness components in a terrestrial orchid, Dactylorhiza majalis (Rchb.) Hunt at Summerh., in relation to environmental factors. Acta Soc. Bot. Pol. 2011; 80(2): 129-138.

9. Tsaliki M, Diekmann M. Population size, pollination and reproductive success in two endangered Genista species. Flora. 2011; 206(3): 246-250. http://dx.doi.org/ 10.1016/j.flora.2010.05.004

10. Petanidou T, Den Nijs JCM, Oostermaijer JGB, Ell is-Ad a m AC.Pollination ecology and patch-dependent reproductive success of the rare perennial Gentiana pneumonanthe L. New Phytol. 1995; 12(1): 155-163. http://dx. doi.org/10.1111/j.1469-8137.1995.tb03019.x

11. Oostermaijer JGB, Luijten SH, Krěnova ZV, Den Nijs JCM. Relationships between population and habitat characteristics and reproduction of the rare Gentiana pneumonanthe L. Conserv. Biol. 1998; 12(5): 1042-1053. http://dx.doi.org/10.1046/j.1523-1739.1998.97090.x

12. Meekers T, Honnay O. Effects of habitat fragmentation on the reproductive success of the nectar-producing orchid Gymnadenia conopsea and the nectarless Orchis mascula. Plant Ecol. 2011; 12(11): 1791-1801. http://dx.doi. org/10.1007/s11258-011-9949-4

13. Jacquemyn H, Brys R. Temporal and spatial variation in flower and fruit production in a food-deceptive 
orchid: a five-year study. Plant Ecol. 2010; 12(1): 145-153 http://dx.doi.org/10.1111/j.1438-8677.2009.00217.x

14. Martinez-Garcia F, Guerrero-Garcia S, Perez-Garcia F. Evaluation of reproductive success and conservation strategies for Senecio coincyi (Asteraceae), a narrow and threatened endemic plant of Central Western Spain. Arch. Biol. Sci. 2012; 64(3): 1001-1016. http:// dx.doi.org/10.2298/ABS1203001G

15. Erhard A. Pollination of Dianthus superbus L. Flora. 1991; 185(2): 99-106.

16. Meusel H, Jäger E, Weinert E. Vergleichende Chorologie der Zentraleuropäischen Flora. Bd.I., Jena: Gustav Fisher Verlag; 1965. (in German).

17. Zając A, Z Zając M. editors. Distribution Atlas of Vascular Plants In Poland. Kraków: Laboratory of Computer Chorology, Institute of Botany, Jagiellonian University, 2001. (in Polish).

18. Regulation of the Minister of Environment of 5 January 2012 on the wild-growing plant species under protection. Dz.U. nr 168, poz. 1764.

19. Zarzycki K, Szeląg Z. Red List of Vascular Plants in Poland In: Mirek Z., Zarzycki K., Wojewoda W., Szeląg Z., editors. Red List of Plants and Fungi in Poland. Kraków: W. Szafer Polish Academy of Sciances, Institute of Botany; 2006, p: 9-20.

20. Zarzycki K. Humid meadows in the environs of Czernichów near Cracow deserving protection. Ochrona Przyrody. 1958; 25: 49-68.

21. Dubiel E. Map of actual vegetation of the city of Cracow. Zeszyty Naukowe UJ. Prace Botaniczne 1991; 22: 121-133.

22. Dubiel E. 1996, Meadows in Cracow. I. Molinio-Arrhenatheretea class. Studia Ośrodka Dokumentacji Fizjograficznej, 1996;24: 145-171.

23. Kotorová I, Le pš J. Comparative ecology of seedling recruitment in an oligotrophic wet meadow - J. Veg. Sci. 1999; 10: 175-186. http://dx.doi.org/10.2307/3237139

24. Špačková I, Lepš J. Variability of seedling recruitment under dominant, moss, and litter removal over four years. Folia Geobot. 2004; 29: 41-55. http://dx.doi.org/ 10.1007/BF02803263

25. Som a natham H, B orges RM. Nocturnal pollination by the carpenter bee Xylocopa tenuiscapa (Apidae) and the effect of floral display on fruit set of Heterophragma quadriloculare (Bignonlaceae) in India. Biotropica. 2001; 33(1): 78-89. http://dx.doi.org/10.1111/j.1744-7429.2001. tb00159.x

26. Kostrakiewicz K. The influence of shadow created by adjacent plants on phenotypic plasticity of endangered species Trollius europaeus L. (Ranunculaceae). Pol . J. Ecol. 2009; 57(4): 625-634.

27. Kostrakiewicz-Gierałt K. The effect of vegetation character on abundance and structure of subpopulations of rare herb Gentiana pneumonanthe L. Pol. J. Ecol. 2013; 61(1):35-43.

28. Kostrakiewicz K. The effect of dominant species on numbers and age structure of Iris sibirica L. population on blue moor-grass meadow in southern Poland. Acta Bot. Soc. Pol. 2007; 76(2): 165-173

29. L oechle C. Partitioning the reproductive effort in clonal plants: a benefit-cost model. Oikos. 1987; 49(2): 199-208.

30. Gardner SN, Mangel M. Modeling investments in seeds, clonal offspring, and translocation in a clonal plant. Ecology, 1999; 80: 1202-1220. http://dx.doi.org/ 10.1890/0012-9658(1999)080[1202:MIISCO]2.0.CO;2

31. Schrautzer J, Fichtner A, Huckauf A, Rasran L, Jensen K. Long-term population dynamics of Dactylorhiza incarnata (L.) Soo after abandonment and reintroduction of mowing. Flora 2011; 206: 622-630. http:// dx.doi.org/10.1016/j.flora.2010.11.008

32. K ř e n ová Z, Le pš J. Regeneration of a Gentiana pneumonanthe population in an oligotrophic wet meadow. J. Veg. Sci. 1996; 7: 107-112. http://dx.doi.org/10.2307/3236422

33. Moora M, Kose M, Jogar U. Optimal management of the rare Gladiolus imbricatus in Estonian coastal meadows indicated by its population structure. Appl. Veg. Sci. 2007; 10(2): 161-168

34. Soons MB, Messelink JH, Jongejans E, Heil GW. Habitat fragmentation reduces grassland connectivity for both short-distance and long-distance winddispersed forbs. J. Ecol. 2005; 93(6): 1214-1225. http:// dx.doi.org/10.1111/j.1365-2745.2005.01064.x

35. Jensen K, Meyer C. Effects of light competition and litter on the performance of Viola palustris and on species composition and diversity of an abandoned fen meadow. Plant Ecol. 2001; 155(2): 169-181. http://dx.doi.org/10. 1023/A:1013270628964

36. Kostrakiewicz-Gierałt K. The impact of neighbourhood and gap character on seedling recruitment of Trollius europaeus L. and Iris sibirica L. in Molinietum caeruleae meadows. Biodiv. Res. Conserv. 2012; 28: 37-44.

37. Blaney SC, Kotanen PM. Effects of fungal pathogens on seeds of native and exotic plants: a test using congeneric pairs. J. Appl. Ecol. 2001; 38: 1104-1113. http://dx. doi.org/10.1046/j.1365-2664.2001.00663.x

38. S chafer M, Kot an en PM. The influence of soil moisture on losses of buried seeds to fungi. Acta Oecol. 2003; 24: 255-263. http://dx.doi.org/10.1016/j.actao.2003.09.001

39. Mikulík J, Sedlářova M, Winter W. Pathogenic fungi on Dianthus superbus subsp. superbus and their influence on host plants germination and survival. Acta Univ. Palacki. Olomuc. Fac. Rer. Nat. Biol. 2002; 39-40: 19-25.

40. Mikulík J, Winter W. Evaluation of factors affecting germination of Dianthus superbus subsp. superbus. Acta Univ. Palacki. Olomuc. Fac. Rer. Nat. Biol. 2001-2002; 39-40: 13-18.

41. Isselstein J, Tallowin JRB, Smith REN. Factors affecting seed germination and seedling establishment of fen-meadow species. Restoration Ecology, 2002; 10(2): 173-184. http://dx.doi.org/10.1046/j.1526100X.2002.00045.x

42. Kotowski W, van Andel J, van Diggelen R, Hogendorf J. Responses of plant species to groundwa- 
ter level and light intensity. Plant Ecol. 2001; 155: 147-156. http://dx.doi.org/10.1023/A:1013214716842

43. Kotowski W, van Diggelen R. Light as an environmental filter in fen vegetation. J. Veg. Sci. 2004; 15: 583594. http://dx.doi.org/10.1111/j.1654-1103.2004.tb02300.x

\section{Cechy historii życiowych i rekrutacja siewek Dianthus superbus L. w płatach łąk o różnym stopniu zarośnięcia}

\section{Streszczenie}

Badania cech historii życiowych oraz rekrutacji siewek w małych, izolowanych populacjach rzadkiego, klonalnego gatunku Dianthus superbus L. były prowadzone w latach 2011-2012 w Krakowie-Kostrzu (Południowa Polska). Obserwacje wykonano na nieużytkowanych łąkach Molinietum caeruleae o różnym stopniu zarośnięcia w procesie sukcesji wtórnej. Płat reprezentujący początkowe stadium sukcesji (P1) był zdominowany przez niskie gatunki tworzące delikatne, płożące pędy, w płacie reprezentującym pośrednie stadium sukcesji (P2) przeważały wysokępowe trawy oraz wysokie ziołorośla, natomiast płat reprezentujący końcowe stadium sukcesji (P3) był częściowo zarośnięty przez krzewy i drzewa. Liczba pędów generatywnych, kwiatów, owoców i nasion Dianthus superbus L. stopniowo malała począwszy od powierzchni P3, przez P2, do P1. Wzrost liczby pędów generatywnych w sąsiedztwie wysokich roślin może przyczynić się do lepszej widoczności kwiatostanów i zwiększyć szanse na wizytę nocnych zapylaczy. Znaczna produkcja owoców i nasion w sąsiedztwie gatunków o dużych zdolnościach konkurencyjnych może podnieść szanse na udane rozsiewanie nasion i kolonizację nowych, być może korzystniejszych siedlisk.

Przeprowadzone obserwacje wykazały, że rekrutacja siewek zachodziła jedynie w sztucznie utworzonych lukach w pokrywie roślinnej i ściółce. Pojaw nowych osobników i ich przeżywalność były znacznie większe w płacie P1 niż na powierzchniach P2 i P3, co może być spowodowane lokalnie stagnującą wodą oraz zmniejszającą się dostępnością światła w kolejnych stadiach sukcesji.

Podsumowując, można stwierdzić że niewielka produkcja pędów generatywnych, kwiatów, owoców i nasion w populacji Diantus superbus L. występującej w płacie zdominowanym przez niskie gatunki łąkowe jest równoważona przez najwyższą rekrutację i przeżywalność siewek. Z drugiej strony, znaczna produkcja pędów generatywnych, kwiatów, owoców i nasion nie wystarczy aby zapewnić utrzymanie populacji na płatach łąk będących w zaawansowanych stadiach sukcesji wtórnej.

Handling Editor: Elżbieta Pogroszewska

This is an Open Access digital version of the article distributed under the terms of the Creative Commons Attribution 3.0 License (creativecommons.org/licenses/by/3.0/), which permits redistribution, commercial and non-commercial, provided that the article is properly cited. 